\title{
Psychiatric complications in human immunodeficiency virus infection
}

\author{
E Koutsilieri, ${ }^{1,2}$ C Scheller, ${ }^{2}$ S Sopper, ${ }^{2}$ V ter Meulen, ${ }^{2}$ and P Riederer ${ }^{1}$ \\ ${ }^{1}$ Clinical Neurochemistry and NPF Center of Excellence Research Laboratory, Department of Psychiatry and \\ Psychotherapy and ${ }^{2}$ Institute of Virology and Immunobiology, University of Wuerzburg, Germany
}

\begin{abstract}
Human immunodeficiency virus (HIV) infection is associated with psychiatric complications, including cognitive impairment, affective disorders, and psychosis. These psychiatric complications impair quality of life, affect disease prognosis, and impede treatment by compromising medication adherence. They also increase the likelihood of HIV transmission, either directly or via their high prevalence rate among drug abusers. In this article, the authors provide a brief overview of the most common psychiatric complications associated with HIV infection and discuss the role of dopamine as a link between psychiatric manifestations and the progression of immunodeficiency infection. Journal of NeuroVirology (2002) 8(suppl. 2), 129-133.
\end{abstract}

Keywords: dementia; dopamine; HIV; mood disorders; psychiatry; psychosis

\section{Introduction}

A large percentage of human immunodeficiency virus (HIV)-positive patients develop a central nervous system (CNS) disorder with neurological and psychiatric symptomatology, referred to as HIVassociated dementia. Prominent clinical CNS manifestation occurs in approximately $30 \%$ of patients with acquired immunodeficiency syndrome (AIDS) (Price et al, 1988), whereas at autopsy a greater proportion of infected individuals exhibit CNS lesions (Gray et al, 1988; Petito, 1988).

The highly active antiretroviral therapy (HAART) suppresses HIV replication, resulting in improved survival and a reduction in the incidence rate of HIV-associated dementia by approximately one-

Address correspondence to Dr. Eleni Koutsilieri, Clinical Neurochemistry and NPF Center of Excellence Research Laboratory, Department of Psychiatry and Psychotherapy, Julius-MaximiliansUniversity, Fuechsleinstrasse 15, 97080 Wuerzburg, Germany. E-mail: eleni.koutsilieri@mail.uni-wuerzburg.de

This study was supported by a grant from the Bundesministerium für Bildung, Wissenschaft, Forschung und Technologie, Germany (BMBF 01 KI 0211), by Max-Planck-Forschungspreis (V. ter Meulen), and by the Whilhelm Sander Stiftung. E.K. is a recipient of the HWP "Programm Chancegleichhert für Frauen in Forschung und Lehre." We thank Dr. Kay Double for careful reading of the manuscript.

Received 20 August 2002; revised 23 August 2002; accepted 12 September 2002. half (Michaels et al, 1998; Moore and Chaisson, 1999). Despite the apparent effectiveness of this treatment, the poor penetration of the blood-brain barrier by antiviral agents, the failure of some drug regimens to control virus replication in infected individuals, and the development of resistant viruses make the CNS vulnerable to HIV-induced damage. As recent advances in treatment have increased, the number of people with CNS signs is expected to rise, emphasizing the need to understand CNS disorders associated with HIV infection. Neurological complications and cognitive impairment in HIV disease have been well characterized but psychiatric changes associated with HIV infection have not received the same attention. This may have resulted from the fact that psychiatric illnesses in HIV infection are often overlooked or wrongly interpreted as reactive psychological changes. Psychiatric disorders associated with HIV infection are an important part of the disease as they influence treatment compliance, and thus the efficacy of antiretroviral therapy, as well as the risk behaviour of HIV-infected patients.

This article briefly overviews the most common neuropsychiatric complications associated with HIV infection, cognitive impairment and HIV-related mood and psychotic disorders, and discusses how they may be neurochemically linked with HIVassociated dementia. 


\section{Psychiatric disorders in HIV infection}

The prevalence of psychiatric disorders in HIVinfected patients ranges widely, depending on the infected risk group, criteria for evaluation, and stage of HIV disease. HIV is not associated with specific psychiatric symptomatology despite initial reports of a characteristic AIDS lethargy disorder (Diederich et al, 1988). The differential diagnosis includes psychiatric symptoms of HIV encephalopathy, psychoreactive disorders, or due to opportunistic CNS infections and tumors.

\section{Cognitive impairment}

The severity of cognitive alterations in HIV infection range from mild cognitive deficits to severe dementia (Navia et al, 1986). Profound dysfunction may occur in the late stages of HIV infection (McArthur et al, 1989), although subtle neuropsychological deficits have been reported in HIV-positive patients in the absence of immunosuppression (Grant et al, 1995). As cognitive impairment associated with HIV infection has been analyzed in detail, it is not our aim to repeat this information. Instead, we would like to present biochemical data from our own laboratory demonstrating that cognition may be impaired very early following infection. Using the simian immunodeficiency virus (SIV)-macaque model, we found a dramatic reduction in cholinergic neurotransmission in hippocampus within 2 months of infection (Koutsilieri et al, 2000). The activity of choline acetyltransferase, presently one of the most used estimates of cognitive dysfunction, was significantly reduced. The cholinergic decline was not correlated with viral load or CNS pathological lesions, indicating rather a deficit related to global immunological or neurochemical changes (Koutsilieri et al, 2000).

\section{Psychotic disorders}

Prevalence of new onset psychosis in HIV-infected patients ranges from $0.5 \%$ to $15 \%$ (Sewell et al, 1994) and seroprevalence studies of patients with psychoses have shown $5-20 \%$ to be HIV positive (Cournos et al, 1991; Susser et al, 1993; Stefan and Catalan, 1995). It appears that psychosis in HIV patients is associated with a higher mortality rate than that in HIV patients without psychotic symptoms (Sewell et al, 1994). To our knowledge, there are no available data that address the relationship between psychosis and the associated HIV disease progression. Furthermore, it is not clear whether new-onset psychosis is related to the dementing processes or mood deterioration.

The presence of a psychotic disorder prior to HIV infection can increase the risk of infection (Cournos et al, 1991), presumably because of high-risk behaviors (Kelly et al, 1992). On the other hand, reports have described new-onset psychosis in the presence of antecedent HIV infection, suggesting that HIV infection induces psychosis (Thomas and Szabadi, 1987; Gabel et al, 1986; Sewell et al, 1994; Harris et al, 1991). It is noteworthy that psychosis that develops following HIV infection may not be associated with encephalopathy (Susser et al, 1997). These findings suggest that neurochemical changes directly related to the virus or indirectly via infected cells may lead to psychosis without the involvement of an HIV encephalopathy. Additionally, other factors may predispose (Susser et al, 1997) individuals to both psychotic disorders and HIV infection. Substance abuse could be such a factor (Tsuang et al, 1982).

\section{Affective disorders}

Depression in HIV-infected individuals has been found to range from $15 \%$ to $40 \%$ (Brown et al, 1992; Treisman et al, 1998; Atkinson et al, 1988), a proportional prevalence significantly higher than that in general population (Blazer et al, 1994; Kessler et al, 1994). Depression may alter the course of HIV infection by impairing immune function or influencing behavior. There is evidence that depression is a risk factor for HIV (McDermott et al, 1994), but depression is also a risk factor for increased substance abuse, which may lead to an enhaced risk of HIV infection (Regier et al, 1990) and is associated with a higher mortality rate (Wilkie et al, 1998; Ickovics et al, 2001).

With regard to treatment of HIV infection, depression has a profound impact on adherence (Singh et al, 1996). Depressed patients exhibit a decreased interest in their safety and may ignore medical advice. Subjects adhering to HAART, however, exhibit a lower prevalence of depressive symptoms (Starace et al, 2002).

Manic syndromes affect approximately $8 \%$ of HIVinfected individuals with immunosuppression without a personal or family history of bipolar disorder (Lyketsos et al, 1993) and mostly appear in late stages of HIV disease. These syndromes are usually referred to as "AIDS mania," and are clinically different from classical mania in symptomatology, disease progression, and treatment (Lyketsos et al, 1997; Ellen et al, 1999). So far, it is unclear whether AIDS mania is a distinct clinical entity or part of the spectrum of HIV dementia, as the development of manic symptoms post infection is often associated with profound cognitive deficits (Lyketsos et al, 1993; McDaniel et al, 1997). The treatment for patients with AIDS mania is particularly difficult. They do not respond well to mood stabilizers, which usually results in delirium. The administration of low-dose antipsychotics has been more efficient (Angelino and Treisman, 2001).

\section{The role of dopamine as a link between HIV infection and psychiatric complications}

One of the factors predictive of which group of HIV-infected individuals is most susceptible to psychiatric complications is substance abuse (Basso and 
Bornstein, 2000). Drug abuse prevalence in infected individuals is high. Studies reported rates as high as $75 \%$ of HIV-positive patients use illicit drugs (Rosenberger et al, 1993; Lyketsos et al, 1994) and a higher incidence of HIV encephalopathy in users of addictive drugs compared to other HIV-infected individuals (Martinez et al, 1995; Bell et al, 1996). It has been postulated that drugs accelerate HIV encephalopathy progression (Pillai et al, 1991; Tyor and Middaugh, 1999; Kibayashi et al, 1996; Phillips et al, 2000). These substances preferentially activate the mesocortical/mesolimbic dopaminergic pathway (Di Chiara and Imperato, 1988) and can induce a psychosis virtually indistinguishable from schizophrenia. The association of drug abuse with psychiatric disorders is high. Nearly half of the infected individuals screening positive for a psychiatric disorder reported the use of illicit drugs (Bing et al, 2001).

Psychiatric disorders, similar to drug action and addiction, are associated with dopaminergic systems. An overactivity of the same dopaminergic pathways mediates the positive symptomatology of psychosis, whereas the blockade of dopaminergic neurotransmission by antipsychotic drugs reduces psychotic signs. Neuroleptics are effective for the treatment of psychotic symptoms in HIV infection, although a reduced dose is advisable as even mild dopamine antagonism can result in extrapyramidal side effects (Hriso et al, 1991). The potential for HIV-infected patients to develop parkinsonian symptomatology following dopamine blocking agents is two- to fourfold greater than that of uninfected psychotic individuals (Hriso et al, 1991), indicating a great vulnerability of dopaminergic systems in HIV-infected patients.

Newer evidence suggests that increased dopamine availability may affect the progression of immunod-

\section{References}

Angelino AF, Treisman GJ (2001). Management of psychiatric disorders in patients infected with human immunodeficiency virus. Clin Infect Dis 33: 847-856.

Atkinson JH Jr, Grant I, Kennedy CJ, Richman DD, Spector SA, McCutchan JA (1988). Prevalence of psychiatric disorders among men infected with human immunodeficiency virus. A controlled study. Arch Gen Psychiatry 45: 859-864.

Basso MR, Bornstein RA (2000). Neurobehavioural consequences of substance abuse and HIV infection. J Psychopharmacol 14: 228-237.

Bell JE, Donaldson YK, Lowrie S, McKenzie CA, Elton RA, Chiswick A, Brettle RP, Ironside JW, Simmonds P (1996). Influence of risk group and zidovudine therapy on the development of HIV encephalitis and cognitive impairment in AIDS patients. AIDS 10: 493499.

Berger JR, Arendt G (2000). HIV dementia: the role of the basal ganglia and dopaminergic systems. J Psychopharmacol 14: 214-221. eficiency infection and may contribute to the pathogenesis of HIV-associated dementia (for further reading, see Berger and Arendt, 2000; Koutsilieri et al, 2002; Nath et al, 2000). Our group showed that selegiline, a substance that increases dopamine availability, and L-DOPA, the precursor of dopamine, caused marked degenerative CNS changes and accelerated viral infection in SIV-macaques (Czub et al, 2001). The safety of dopaminergic drugs in the clinical management of HIV-infected patients should therefore be reconsidered, particularly as psychostimulants, antidepressants, and antiparkinsonian agents, all substances that increase dopaminergic availability, are currently advocated to attenuate associated psychiatric symptoms.

\section{Concluding remarks}

As patients live longer under HAART, the number of HIV-infected persons with psychiatric disorders may increase. The recognition of psychiatric disorders in HIV clinics is an issue of supreme importance. It is time that psychiatric services realize that HIV may be a new cause of psychiatric manifestations. Early identification of the spectrum of psychiatric disorders attributable to the direct neuropathic effects of HIV, and the development of effective and appropriate treatment strategies, are required.

Dopamine appear to be implicated in the pathogenesis of HIV-associated dementia, the effects of substance abuse, and the generation of psychiatric disorders and may be the key factor linking these probably independent processes. Research focusing on dopaminergic regulation in HIV-associated dementia and in related CNS disorders is required to clarify the exact role of this neurotransmitter in HIV infection.

Bing EG, Burnam MA, Longshore D, Fleishman JA, Sherbourne CD, London AS, Turner BJ, Eggan F, Beckman R, Vitiello B, Morton SC, Orlando M, Bozzette SA, Ortiz-Barron L, Shapiro M (2001). Psychiatric disorders and drug use among human immunodeficiency virus-infected adults in the United States. Arch Gen Psychiatry 58: 721-728.

Blazer DG, Kessler RC, McGonagle KA, Swartz MS (1994). The prevalence and distribution of major depression in a national community sample: the National Comorbidity Survey. Am J Psychiatry 151: 979-986.

Brown GR, Rundell JR, McManis SE, Kendall SN, Zachary R, Temoshok L (1992). Prevalence of psychiatric disorders in early stages of HIV infection. Psychosom Med 54: 588-601.

Cournos F, Empfield M, Horwath E, McKinnon K, Meyer I, Schrage H, Currie C, Agosin B (1991). HIV seroprevalence among patients admitted to two psychiatric hospitals. Am J Psychiatry 148: 12251230. 
Czub S, Koutsilieri E, Sopper S, Czub M, Stahl-Hennig C, Müller JG, Pedersen V, Gsell W, Heeney JL, Gerlach M, Gosztonyi G, Riederer P, ter Meulen V (2001). Enhancement of CNS pathology in early simian immunodeficiency virus infection by dopaminergic drugs. Acta Neuropathol 101: 85-91.

Di Chiara G, Imperato A (1988). Drugs abused by humans preferentially increase synaptic dopamine concentrations in the mesolimbic system of freely moving rats. Proc Natl Acad Sci USA 85: 5274-5278.

Diederich N, Karenberg A, Peters UH (1988). [Psychopathologic pictures in HIV infection: AIDS lethargy and AIDS dementia] (in German). Fortschr Neurol Psychiatr 56: 173-185.

Ellen SR, Judd FK, Mijch AM, Cockram A (1999). Secondary mania in patients with HIV infection. Aust $N$ Z J Psychiatry 33: 353-360.

Gabel RH, Barnard N, Norko M, O’Connell RA (1986). AIDS presenting as mania. Compr Psychiatry 27: 251254.

Grant I, Heaton RK, Atkinson JH (1995). Neurocognitive disorders in HIV-1 infection. HNRC Group. HIV Neurobehavioral Research Center. Curr Top Microbiol Immunol 202: 11-32.

Gray F, Gherardi R, Scaravilli F (1988). The neuropathology of the acquired immune deficiency syndrome (AIDS). A review. Brain 111( Pt 2): 245-266.

Harris MJ, Jeste DV, Gleghorn A, Sewell DD (1991). Newonset psychosis in HIV-infected patients. J Clin Psychiatry 52: 369-376.

Hriso E, Kuhn T, Masdeu JC, Grundman M (1991). Extrapyramidal symptoms due to dopamine-blocking agents in patients with AIDS encephalopathy. Am J Psychiatry 148: 1558-1561.

Ickovics JR, Hamburger ME, Vlahov D, Schoenbaum EE, Schuman P, Boland RJ, Moore J (2001). Mortality, CD4 cell count decline, and depressive symptoms among HIV-seropositive women: longitudinal analysis from the HIV Epidemiology Research Study. JAMA 285: 14661474.

Kelly JA, Murphy DA, Bahr GR, Brasfield TL, Davis DR, Hauth AC, Morgan MG, Stevenson LY, Eilers MK (1992). AIDS/HIV risk behavior among the chronic mentally ill. Am J Psychiatry 149: 886-889.

Kessler RC, McGonagle KA, Zhao S, Nelson CB, Hughes M, Eshleman S, Wittchen HU, Kendler KS (1994). Lifetime and 12-month prevalence of DSM-III-R psychiatric disorders in the United States. Results from the National Comorbidity Survey. Arch Gen Psychiatry 51: 8-19.

Kibayashi K, Mastri AR, Hirsch CS (1996). Neuropathology of human immunodeficiency virus infection at different disease stages. Hum Pathol 27: 637-642.

Koutsilieri E, Czub S, Scheller C, Sopper S, Tatschner T, Stahl-Hennig C, ter Meulen V, Riederer P (2000). Brain choline acetyltransferase reduction in SIV infection. An index of early dementia? Neuroreport 11: 2391-2393.

Koutsilieri E, Sopper S, Scheller C, ter Meulen V, Riederer $P$ (2002). Involvement of dopamine in the progression of AIDS dementia complex. J Neural Transm 109: 399-410.

Lyketsos CG, Hanson A, Fishman M, McHugh PR, Treisman GJ (1994). Screening for psychiatric morbidity in a medical outpatient clinic for HIV infection: the need for a psychiatric presence. Int J Psychiatry Med 24: 103-113.

Lyketsos CG, Hanson AL, Fishman M, Rosenblatt A, McHugh PR, Treisman GJ (1993). Manic syndrome early and late in the course of HIV. Am J Psychiatry 150: 326327.

Lyketsos CG, Schwartz J, Fishman M, Treisman G (1997). AIDS mania. J Neuropsychiatry Clin Neurosci 9: 277279.

Martinez AJ, Sell M, Mitrovics T, Stoltenburg-Didinger G, Iglesias-Rozas JR, Giraldo-Velasquez MA, Gosztonyi G, Schneider V, Cervos-Navarro J (1995). The neuropathology and epidemiology of AIDS. A Berlin experience. A review of 200 cases. Pathol Res Pract 191: 427-443.

McArthur JC, Cohen BA, Selnes OA, Kumar AJ, Cooper K, McArthur JH, Soucy G, Cornblath DR, Chmiel JS, Wang $\mathrm{MC}$, et al (1989). Low prevalence of neurological and neuropsychological abnormalities in otherwise healthy HIV-1-infected individuals: results from the multicenter AIDS Cohort Study. Ann Neurol 26: 601-611.

McDaniel JS, Purcell DW, Farber EW (1997). Severe mental illness and HIV-related medical and neuropsychiatric sequelae. Clin Psychol Rev 17: 311-325.

McDermott BE, Sautter FJ Jr, Winstead DK, Quirk T (1994). Diagnosis, health beliefs, and risk of HIV infection in psychiatric patients. Hosp Community Psychiatry 45: 580-585.

Michaels SH, Clark R, Kissinger P (1998). Declining morbidity and mortality among patients with advanced human immunodeficiency virus infection. $N$ Engl J Med 339: $405-406$.

Moore RD, Chaisson RE (1999). Natural history of HIV infection in the era of combination antiretroviral therapy. AIDS 13: 1933-1942.

Nath A, Anderson C, Jones M, Maragos W, Booze R, Mactutus C, Bell J, Hauser KF, Mattson M (2000). Neurotoxicity and dysfunction of dopaminergic systems associated with AIDS dementia. J Psychopharmacol 14: 222-227.

Navia BA, Jordan BD, Price RW (1986). The AIDS dementia complex: I. Clinical features. Ann Neurol 19: 517-524.

Petito CK (1988). Review of central nervous system pathology in human immunodeficiency virus infection. Ann Neurol 23(Suppl.): S54-S57.

Phillips TR, Billaud JN, Henriksen SJ (2000). Methamphetamine and HIV-1: potential interactions and the use of the FIV/cat model. J Psychopharmacol 14: 244-250.

Pillai R, Nair BS, Watson RR (1991). AIDS, drugs of abuse and the immune system: a complex immunotoxicological network. Arch Toxicol 65: 609-617.

Price RW, Brew B, Sidtis J, Rosenblum M, Scheck AC, Cleary P (1988). The brain in AIDS: central nervous system HIV-1 infection and AIDS dementia complex. Science 239: 586-592.

Regier DA, Farmer ME, Rae DS, Locke BZ, Keith SJ, Judd LL, Goodwin FK (1990). Comorbidity of mental disorders with alcohol and other drug abuse. Results from the Epidemiologic Catchment Area (ECA) Study. JAMA 264: 2511-2518.

Rosenberger PH, Bornstein RA, Nasrallah HA, Para MF, Whitaker CC, Fass RJ, Rice RR Jr (1993). Psychopathology in human immunodeficiency virus infection: lifetime and current assessment. Compr Psychiatry 34: 150-158.

Sewell DD, Jeste DV, Atkinson JH, Heaton RK, Hesselink JR, Wiley C, Thal L, Chandler JL, Grant I (1994). HIV-associated psychosis: a study of 20 cases. San Diego HIV Neurobehavioral Research Center Group. Am J Psychiatry 151: 237-242. 
Singh N, Squier C, Sivek C, Wagener M, Nguyen MH, Yu VL (1996). Determinants of compliance with antiretroviral therapy in patients with human immunodeficiency virus: prospective assessment with implications for enhancing compliance. AIDS Care 8: 261-269.

Starace F, Bartoli L, Aloisi MS, Antinori A, Narciso P, Ippolito G, Ravasio L, Moioli MC, Vangi D, Gennero L, Coronado OV, Giacometti A, Nappa S, Perulli ML, Montesarchio V, La Gala A, Ricci F, Cristiano L, De Marco M, Izzo C, Pezzotti P, D’Arminio Monforte A (2002). Cognitive and affective disorders associated to HIV infection in the HAART era: findings from the NeuroICONA study Cognitive impairment and depression in HIV/AIDS. The NeuroICONA study. Acta Psychiatr Scand 106: 20-26.

Stefan MD, Catalan J (1995). Psychiatric patients and HIV infection: a new population at risk? Br J Psychiatry 167: 721-727.

Susser E, Colson P, Jandorf L, Berkman A, Lavelle J, Fennig S, Waniek C, Bromet E (1997). HIV infection among young adults with psychotic disorders. Am J Psychiatry 154: 864-866.
Susser E, Valencia E, Conover S (1993). Prevalence of HIV infection among psychiatric patients in a New York City men's shelter. Am J Public Health 83: 568570.

Thomas CS, Szabadi E (1987). Paranoid psychosis as the first presentation of a fulminating lethal case of AIDS. Br J Psychiatry 151: 693-695.

Treisman G, Fishman M, Schwartz J, Hutton H, Lyketsos C (1998). Mood disorders in HIV infection. Depress Anxiety 7: 178-187.

Tsuang MT, Simpson JC, Kronfol Z (1982). Subtypes of drug abuse with psychosis. Demographic characteristics, clinical features, and family history. Arch Gen Psychiatry 39: 141-147.

Tyor WR, Middaugh LD (1999). Do alcohol and cocaine abuse alter the course of HIV-associated dementia complex? J Leukoc Biol 65: 475-481.

Wilkie FL, Goodkin K, Eisdorfer C, Feaster D, Morgan R, Fletcher MA, Blaney N, Baum M, Szapocznik J (1998). Mild cognitive impairment and risk of mortality in HIV-1 infection. J Neuropsychiatry Clin Neurosci 10: 125132. 